\title{
Active Learning: Basic Science Workshops, Clinical Science Cases, and Medical Role-Playing in an Undergraduate Biology Course
}

\author{
Frank C. Church
}

check for updates

Citation: Church, F.C. Active Learning: Basic Science Workshops, Clinical Science Cases, and Medica Role-Playing in an Undergraduate Biology Course. Educ. Sci. 2021, 11, 370. https://doi.org/10.3390/ educsci11080370

Academic Editor: Eleanor Dommett

Received: 30 June 2021

Accepted: 19 July 2021

Published: 21 July 2021

Publisher's Note: MDPI stays neutral with regard to jurisdictional claims in published maps and institutional affiliations.

Copyright: (C) 2021 by the author. Licensee MDPI, Basel, Switzerland. This article is an open access article distributed under the terms and conditions of the Creative Commons Attribution (CC BY) license (https:// creativecommons.org/licenses/by/ $4.0 /)$.
Laboratory Medicine, Department of Pathology, School of Medicine, University of North Carolina, Chapel Hill, NC 27599, USA; fchurch@med.unc.edu

\begin{abstract}
Effective undergraduate courses increasingly blend elements of active learning with a more traditional lecture format. Designing and implementing active learning sessions that engage, educate, and are challenging and workable in a group setting are essential for student learners. In addition, active learning sessions take concepts of fundamental knowledge and apply them to a more relevant and real-world environment. Thus, effective active learning lesson plans enable students to thrive in their educational experience, and this potentially enhances material retention. Presented here are examples of the critical components of active learning engagement in an undergraduate biology course. First, basic science workshops let students apply basic scientific principles to biomedical science scenarios. Second, clinical science case studies help students understand the interplay between basic and clinical sciences in a patient-based medical case format. Finally, medical roleplaying allows student teams to understand the complexity of medical care, moving from the patient's presenting symptoms to formulating a diagnosis and treatment plan. These exercises strengthen several aspects of active learning, especially those related to student-team-based collaboration, conversation, coordination, and compilation.
\end{abstract}

Keywords: active learning; active learning subtypes; team-based skills; medical role-playing; basic science workshops; clinical science cases; undergraduate biology

\section{Introduction and Background}

\subsection{Implementing Active Learning Activities}

"True teachers are those who use themselves as bridges over which they invite their students to cross; then, having facilitated their crossing, joyfully collapse, encouraging them to create their own." Nikos Kazantzakis

Compared to traditional lecturing styles, active learning is a popular teaching method that engages students with subject material to enhance the learning experience [1-13]. Active learning was initially defined by Bonwell and Elson [1] as "students doing things and thinking about the things they are doing." Felder and Brent [7] refined the active learning definition as "anything course-related that all students in a class session are called upon to do, other than simply watching, listening, and taking notes." It can be challenging to use these brief but broad-based definitions to blend aspects of active learning into a more traditional lecture-based course. Thus, integrating these elements of active learning into a traditional lecture format requires course directors to have a strong understanding of active learning features.

Courses that use active learning have reported reductions in failure rates and increased student comprehension in STEM (Science, Technology, Engineering, and Mathematics)associated courses [14-17]. Therefore, while we remain committed to the concept of lecturing, blending elements of active learning components with lectures may allow student learners to be better informed and educated in STEM courses. In addition, using different 
forms of learning may enhance each student's learning potential, since we now understand that each student learns differently from their peers $[18,19]$.

\subsection{Working Definition of Active Learning}

Recently, we (McGreevy and Church, see [20]) presented a working definition of active learning by referencing historically relevant active learning articles on fundamental concepts [1-13] that are reflective of the authors' own teaching experiences [20]. In addition, we added perspectives that described the methods, goals, and outcomes of active learning and integrated these foundational principles of education: student-centered interactive teaching, group activity, team-based skills, and inclusion of all students [20]. This working definition of active learning is shown in Figure 1.
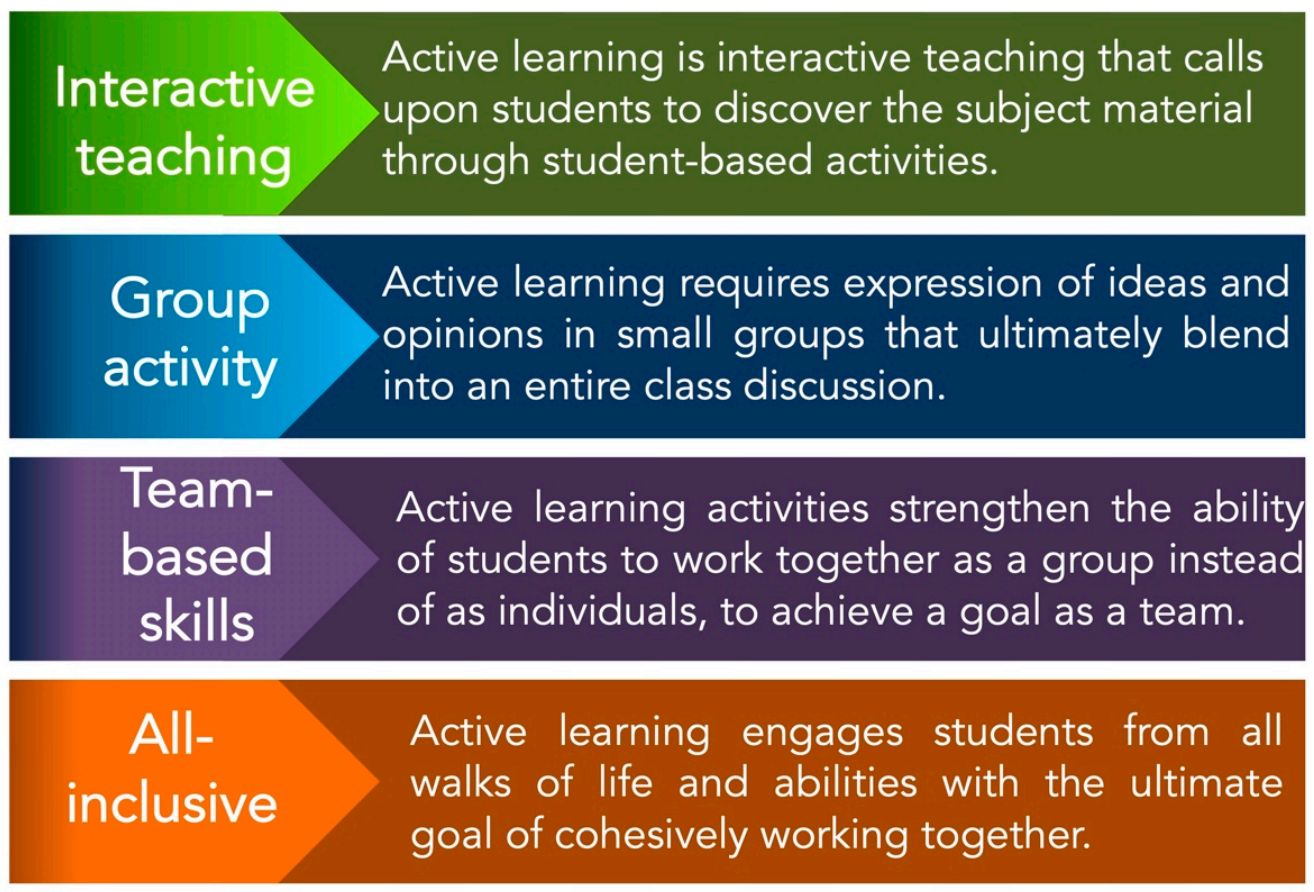

Figure 1. A working definition of active learning (also see McGreevy and Church [20] for further information).

\subsection{Developing and Evaluating Active Learning Subtypes}

Like the hierarchical components in Bloom's Revised Taxonomy on Learning [21-26], we divided active learning into five subtypes: Recognition, Exchanging, Reflective, Constructive, and Analytical [20], situated from the least to the most advanced level of interaction, respectively. In our previous work, focused on an upper-level undergraduate biology course [20], we reasoned that three types of knowledge form the foundation of learning: technical understanding, which is the knowledge of terminology, facts, and recalls; theoretical understanding, which is the knowledge of reasoning and feelings; and systematic understanding, which is the knowledge of applying principles to synthesize answers and to diagnose problems. In Figure 2, the five active learning subtypes are given, aligned with the three types of learning knowledge, followed by a description of the aspects of active learning utilized within each of the subtypes. Using this framework of active learning subtypes allows the teacher to select which component(s) offer(s) the best fit for combining active learning into an existing lecture-based course, or as the starting point for developing a new active-learning-based program. 


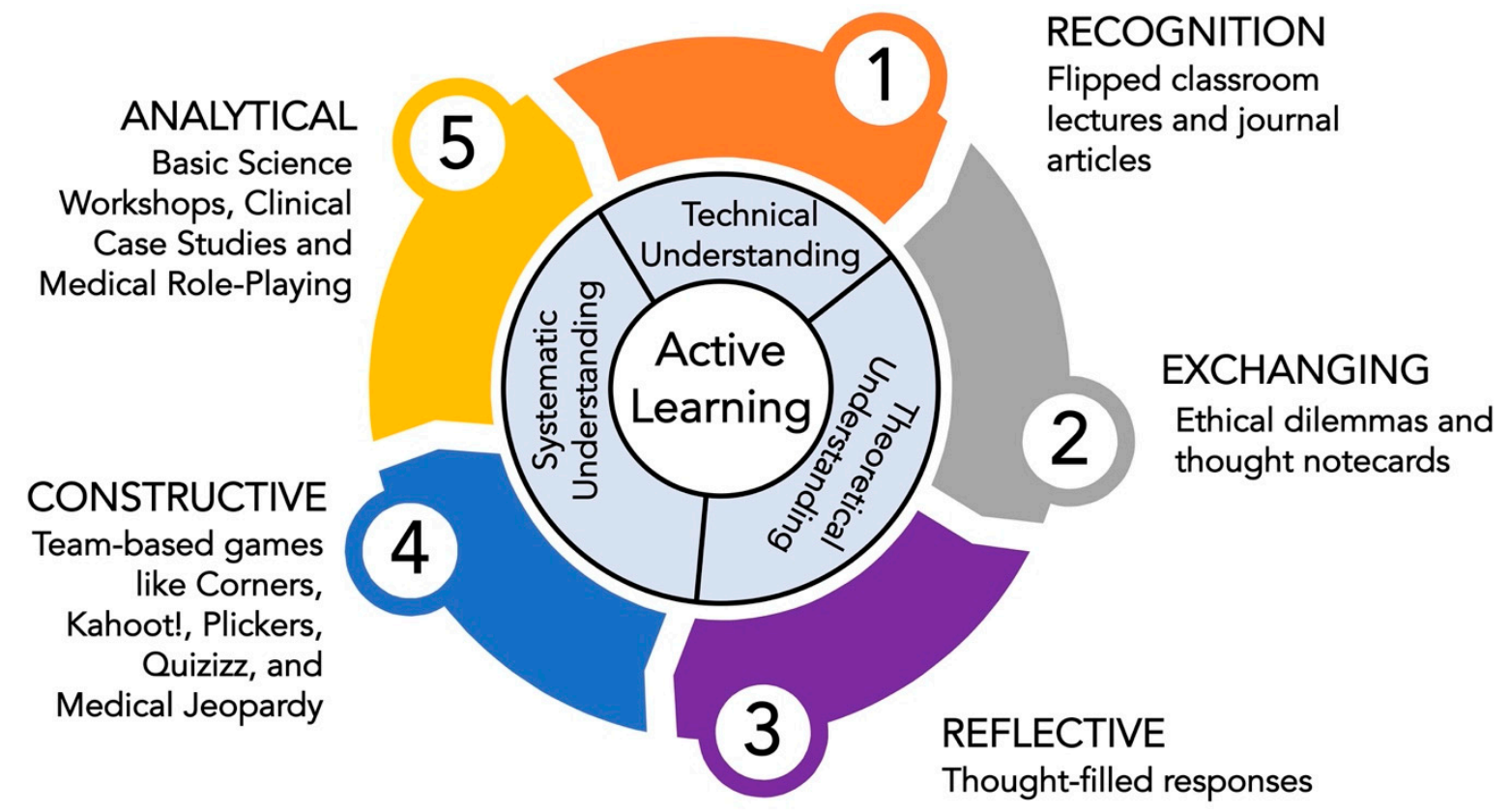

Figure 2. A description of active learning subtypes, the associated learning taxonomy, and the types of classroom experience(s) [20].

\subsection{The Challenge of Active Learning from the Instructor's Viewpoint}

One vital aspect of active learning from the teaching perspective is that of merging class content with student engagement. Actively engaging the student learner is just one benefit to this teaching method. By contrast, the more traditional lecture, with more passive student engagement, typically prevails in many higher education classes. This reluctance may be because it is easier to prepare a focused lecture than the intricacies of an active learning session. Possibly, there are fewer "show-and-tell"-type active learning publications. Here are two recent outstanding examples of such framework-type papers; however, there needs to be more. $\mathrm{Ng}$ and Newpher [27] recently provided an example of designing and implementing team-based learning (TBL) in an undergraduate neuroscience course. Moreover, Penner et al. [28] recently described the use of high-impact practices (HIPs) like makerspace classes and course-based undergraduate research experiences (CUREs) in STEM disciplines.

Notably, several advances have been reported when using active learning in STEM and health care higher education settings. These include the positive effect of the flipped classroom versus the traditional classroom [29], exploring inclusion in active learning [30], novel educational practices [31], and revisiting student beliefs in learning through active learning [32]. However, the importance of proper preparation for using the more complex concept of active learning was noted, as students in some situations have remained unconvinced when execution is lacking [33]. Thus, there remain challenges to using active learning in higher education, where one moves from being the lecturer to become the facilitator. This paper aims not to convince someone to embrace active learning in every lecture but to consider adopting some of the active learning features in one's teaching effort.

\subsection{Strategy for Implementing Analytical Engagement in Active Learning}

As shown in Figure 2, analytical engagement is the most advanced level of active learning. This active learning subtype can be further defined by student discovery and tends to consume the most time. Key descriptive terms for analytical engagement include creating, imagining, testing a hypothesis, and making a diagnosis. For the student learner, mastering the elements of analytical engagement requires deep critical thinking, the application of 
knowledge to the new subject material, research, and extensive group discussion and collaboration. For the course director (active learning facilitator), preparing and planning for analytical engagement is equally time-consuming, yet rewarding. Furthermore, there is a need for clarity as one designs analytical engagement events for the student learners to complete on time and gain (lasting) knowledge, if possible.

The overall goal is to present a strategy that can be used to implement three types of analytical engagement: medical role-playing, basic science workshops, and clinical science cases. The ultimate objective is to broaden the instructor's view of active learning by providing examples of a higher-order form of group interactions.

\section{Methods}

\subsection{Description of the Course}

F.C.C. has been the sole lecturer in the undergraduate biology/pathology course entitled "Biology of Blood Diseases" since its beginning in 1996. The course has four units. It provides 34 topics, covering the biological mechanism and progression of blood and blood-forming organ diseases from a medical and pathological perspective, 13 of which are taught with pre-specified active learning activities. Active learning has been used since 2012. The course has been taught in honors (which enrolls $\sim 25$ students) and non-honors sections (which enrolls $\sim 70$ students). The students are mainly seniors $(>90 \%)$, with a focus on health-related career paths (medicine, dentistry, physician assistant, nursing, pharmacy, occupational therapy, public health, and graduate school in life/health sciences). Furthermore, the students have already passed core biology courses. Most of the students enrolled in this course are majoring in biology, psychology, nutrition, exercise and sport science, epidemiology, or anthropology. McGreevy and Church [20] provide additional details regarding active learning subtypes, traditional lecture topics, examinations, grading, course surveys, and adapting the course in the presence of COVID-19.

\subsection{Description of Course Survey}

Since 2012, a student survey on active learning in the course, as modified from Vasan et al. [34], has been given yearly to the students on a voluntary basis [20]. The final question on the survey is open-ended and states, "Please Add Any Additional Comments Here (Optional)." In the Discussion section, selected student comments are given, compiled over the years from this final query.

\subsection{Essential Components to Analytical-Based Active Learning Sessions}

Given in Table 1 are some key components to consider while one is developing analytical-based active learning subtype activities, specifically, basic science workshops, clinical science cases, and medical role-playing.

\subsection{Description of Analytical Engagement Activities}

Basic science workshops contain a series of questions (multiple choice and short answer) that use the basic science and biomedical science aspects/components of the class material and usually include some medical aspects to the science. The multiple-choice questions are answered in class using the immediate feedback assessment technique, also known as IF-AT scratch-off cards (Epstein Educational Enterprises, 7650 Elbrook Ave., Cincinnati, Ohio 45237, USA). In a Zoom-based meeting with groups in breakout rooms, the students used the Group Readiness Assurance Testing Online Program created by Dr. Gary Theilman (School of Pharmacy at the University of Mississippi). Questions and cases were composed and obtained/modified from many sources [35-47]. 
Table 1. Useful Components of Analytical Engagement in Active Learning Sessions.

\begin{tabular}{|c|c|c|}
\hline Activity & Key Words/Key Concepts & Description \\
\hline Basic Science Workshops & $\begin{array}{c}\text { Fundamentals of Science to Bioscience } \\
\text { and Biomedicine; } \\
\text { Translation of key concepts of basic } \\
\text { science; } \\
\text { Student discovery }\end{array}$ & $\begin{array}{c}\text { A series of questions that address the science components } \\
\text { of the class material, and usually end by including some } \\
\text { medical aspect to the science. Overall, the goal of these } \\
\text { exercises is to highlight or demonstrate the importance of } \\
\text { basic science principles, applied to a bioscience or } \\
\text { biomedicine scenario. }\end{array}$ \\
\hline Clinical Science Cases & $\begin{array}{l}\text { Diagnosis, prognosis; Understand } \\
\text { medical test results;Appreciate } \\
\text { principles of basic science in medicine }\end{array}$ & $\begin{array}{l}\text { Worksheets with medical scenarios in which the group } \\
\text { will be asked to provide a diagnosis for the patient, order } \\
\text { the necessary tests, recommend appropriate therapy, or } \\
\text { describe the biological origin and expected disease } \\
\text { progression. Students are encouraged to research online to } \\
\text { help find the answers. }\end{array}$ \\
\hline Medical Role-Playing & $\begin{array}{c}\text { Imagination; } \\
\text { Play-acting a role; } \\
\text { Interpreting medical tests; } \\
\text { Understand the power of a team and } \\
\text { teamwork; } \\
\text { What the diagnosis and prognosis truly } \\
\text { mean to the patient/family }\end{array}$ & $\begin{array}{l}\text { Each member in the group acts according to a } \\
\text { pre-assigned medical role, with any script ad-libbed. As } \\
\text { each person proceeds, new information is gathered and } \\
\text { students must diagnose the patient, order the necessary } \\
\text { tests, recommend appropriate therapy, and discuss the } \\
\text { expected disease progression. Students are encouraged to } \\
\text { research online to help find the answers and complete a } \\
\text { limited History and Physical Report. }\end{array}$ \\
\hline
\end{tabular}

Clinical science cases have descriptions of medical scenarios. The student groups are asked to diagnose the patient's illness, order the necessary tests, recommend appropriate therapy, or describe the biological origin and the expected disease progression. The cases represent important fundamental science principles from class; therefore, going through them together in class facilitates the learning process for the class. Additionally, students are encouraged to research online to help complete the answers. Cases were written, gathered, and used from several reference sources [35-47].

Medical role-playing allows each member of the group to act according to a preassigned medical role, for example, a patient, spouse/partner, nurse, medical student, physician, and medical specialist. As each person proceeds with their interview, information is assembled, and students must work on a differential diagnosis, decide which tests need to be ordered, recommend appropriate therapy, and describe the expected disease progression. Students are encouraged to research online, to help find the answers, and complete a limited History and Physical (H\&P) Report. The H\&P contains these sections: Chief Complaints; History of Present Illness/Past Health; Personal/Family History; Physical Exam/Lab Results; Diagnosis/Prognosis; and Strategy for Treatment. Dr. Raj Kasthuri (Department of Medicine, UNC School of Medicine) suggested the clinical conditions and parameters given for each patient. F.C.C. provided the 'description' of each patient and family member, respectively (the intention was to describe real people, so that the students would connect with them more deeply as they described their medical problems). Typically, the room used for the class had nine tables, which can accommodate 6-7 students per table. There are three cases, and each case was assigned to three groups. Each group would discuss a single case in a 50-min class period and then each group would present their findings to the class.

Table 2 details the active learning sessions, and the course topics are highlighted in bold font, identifying where basic science workshops, clinical cases, and medical roleplaying were used during the course. 
Table 2. Analytical Engagement Component of the Active Learning Sessions *.

\begin{tabular}{|c|c|}
\hline Course Topic & Active Learning Module Description \\
\hline \multicolumn{2}{|l|}{ Unit 1} \\
\hline $\begin{array}{l}\text { Hemoglobin Structure and } \\
\text { Function }\end{array}$ & $\begin{array}{l}\text { A short at-home lecture, followed by in-class, small group } \\
\text { activities: basic science workshop, multiple-choice } \\
\text { questions on hemoglobin answered by scratch-off forms. }\end{array}$ \\
\hline Iron-deficiency Anemia & $\begin{array}{l}\text { A short at-home lecture and paper to read, titled } \\
\text { "Mechanisms of Mammalian Iron Homeostasis". This was } \\
\text { followed by in-class multiple-choice questions using a } \\
\text { combined basic science workshop. }\end{array}$ \\
\hline Sickle Cell Anemia & $\begin{array}{c}\text { A short at-home lecture and paper to read, titled "Sickle-cell } \\
\text { Disease". This was followed by research in small groups and } \\
\text { a clinical case study form. }\end{array}$ \\
\hline
\end{tabular}

\begin{tabular}{c}
\hline Unit 2 \\
\hline Neutrophils and Acute \\
Inflammation \\
Lymphocytes and Lymphatics \\
Monocytes and Chronic \\
Inflammation \\
Overview of Leukemia, \\
Lymphoma, Myeloma and \\
Principles of Cancer \\
Lymphomas
\end{tabular}

A short at-home lecture, followed by an in-class, small group computer-based game, "Corners", a basic science workshop.

Each group discussed and answered 9 questions.

A short at-home lecture followed by in-class small groups researching and completing three brief clinical case studies.

A short at-home lecture and brief in-class review.

A short at-home lecture followed by in-class medical role-playing. Groups complete a History and Physical and present the case to the class.

A short at-home lecture followed by an in-class, small group

"Cancer Jeopardy" game. Each group discussed and responded by displaying color-coded cards.

Unit 3 and Unit 4

HIV Disease/AIDS Virology

A short at-home lecture and review article to read, "Mechanisms of Disease: Where does HIV Live?". This was followed by an in-class, written thought response notecard exchange among students, a basic science workshop, and a clinical science case.

A short at-home lecture and PubMed biography search on

HIV Disease. This was followed by in-class, group

HIV Disease/AIDS Therapy presentations on students' findings, and ethical dilemmas were presented in class by exchanging and discussing student notecard responses.

Platelet Disorders

A short at-home lecture followed by in-class, medical role-playing. Groups complete a History and Physical Report and present the case to the class.

Venous Thrombosis

A short at-home lecture followed by an in-class short lecture and group multiple-choice questions answered by scratch-off forms, and combined basic science workshop/clinical cases. A short at-home lecture, clinical science cases, followed by a student notecard exchange and the computer-based game

Atherosclerosis and Arterial Thrombosis "Kahoot!"

* Analytical engagment sessions are identiied in bold print.

\section{Activity}

\subsection{Basic Science Workshops}

An essential feature of this course is the merging of basic science aspects into bioscience/biomedicine. To describe the following basic science workshop on hemoglobin and red blood cells, the class had lectures on the following topics: Blood Composition; Hematopoiesis; Erythropoiesis, General Aspects of Anemia; and Hemoglobin Structure and Function. One feature used for active learning is the accumulation of knowledge from 
class to class and revisiting concepts previously covered by asking questions related to past lectures.

Active Learning Basic Science Workshop on Hemoglobin, Red Blood Cells, and Hemoglobin Breakdown Products

1. What is the primary role of protoporphyrin (IX) as it relates to hemoglobin function?
A. A binding site for iron
B. A binding site for 2,3-DPG
C. A binding site to transport $\mathrm{CO}_{2}$
D. Critical for maintaining blood $\mathrm{pH}$
E. Molecular stability provided by two arginines

2. Which of the following is the most correct statement that describes the various components of hemoglobin found in normal adult red blood cells?
A. $\quad \alpha$ (alpha) globin gene located on chromosome 11
B. $\quad \beta$ (beta) globin gene located on chromosome 16
C. $\quad \varepsilon$ (epsilon) globin is the major globin protein
D. Hemoglobin has 2- $\alpha$ (alpha) and 2 non- $\alpha$ (alpha) globin polypeptide chains

3. What is the overall composition of normal adult hemoglobin in red blood cells?
A. $90 \% \mathrm{HbA} ; 8-9 \% \mathrm{HbA}_{2} ; 2 \% \mathrm{HbF}$
B. $\quad 96-98 \% \mathrm{HbA} ; 1.5-3 \% \mathrm{HbA}_{2} ; 0.5-0.8 \% \mathrm{HbF}$
C. $80-85 \% \mathrm{HbA} ; 2-3 \% \mathrm{HbA}_{2} ; 10 \% \mathrm{HbF}$
D. $70 \% \mathrm{HbA} ; 18 \% \mathrm{HbA}_{2} ; 11 \% \mathrm{HbF} ; 1 \% \mathrm{HbA}_{2}$

4. Hemoglobin is a "model protein" known to have a structure because it is a tetramer, which is important in its physiological function of carrying/delivering oxygen throughout the body.
A. Primary
B. Super
C. Secondary
D. Tertiary
E. Quaternary

5. Which of the following statements best describes plasma?
A. blood that has no red blood cells
B. the proteins of blood, derived by separating them by paper filtration
C. the liquid portion of blood after it has clotted
D. the liquid portion of blood including clotting factors before clotting

6. Fill in the blank space with the appropriate number below, respectively. Each hemoglobin molecule contains __ heme groups with globin chains, and hemoglobin maximally binds _ oxygen molecules. The oxygen binds at the coordination site of iron.
A. $1,1,1,4$ th
B. $4,4,4,6$ th
C. $2,4,2,5$ th
D. $4,4,2,2$ nd

Answers to the multiple-choice questions: 1, A; 2, D; 3, B; 4, E; 5, D; 6, B.

This information is to be used in Question 7. A 50-year-old male has a 10-day history of flu-like symptoms, yellowing of the whites of his eyes, fatigue, nausea, and loss of appetite. He has noticed that his urine is tea-colored and dark in color. On physical examination, he has tenderness in the right upper quadrant. He states that the only life-change was that 6 months ago, he got a new tattoo shaped in a red heart, with his partner's name in script across it (he had received a 50\% discount because the autoclave used to sterilize needles was broken and there was only a previously opened red ink vial available in the tattoo shop). You get the following Clinical Chemistry/Hematology Laboratories results 
(abnormal results are shown in "bold"). Perform an internet search while discussing these results in Table 3.

Table 3. Clinical Chemistry/Hematology Laboratories Results *.

\begin{tabular}{ccc}
\hline Test & Patient & Normal Ranges \\
\hline Glucose $(\mathrm{mg} / \mathrm{dL})$ & 108 & $(65-110 \mathrm{mg} / \mathrm{dL})$ \\
BUN (mg/dL) & 22 & $(7-24 \mathrm{mg} / \mathrm{dL})$ \\
Creatinine $(\mathrm{mg} / \mathrm{dL})$ & 1.0 & $(0.6-1.3 \mathrm{mg} / \mathrm{dL})$ \\
LDH (U/L) & 420 & $(100-250 \mathrm{U} / \mathrm{L})$ \\
AST (U/L) & 603 & $(5-55 \mathrm{U} / \mathrm{L})$ \\
GGT (U/L) & 97 & $(5-50 \mathrm{U} / \mathrm{L})$ \\
Bilirubin (total in mg/dL) & 6.7 & $(0.02-1.5 \mathrm{mg} / \mathrm{dL})$ \\
Bilirubin (direct in mg/dL) & 2.5 & $(0.02-0.18 \mathrm{mg} / \mathrm{dL})$ \\
Uric acid $(\mathrm{mg} / \mathrm{dL})$ & 7.8 & $(3-8.5 \mathrm{mg} / \mathrm{dL})$ \\
\hline
\end{tabular}

* Abnormal test values are are identiied in bold print.

7. (A) What aspects of his symptoms relate to hemoglobin and/or red blood cell physiology/pathology? (B) What organ is likely to be most affected? (C) What is up with the tattoo in relation to the patient's illness? (D) Based on his symptoms and test results, what is the probable diagnosis?

Answers to the case:

(A) As red blood cells age, they are broken down naturally in the body. Bilirubin is released from the destroyed red blood cells and passed on to the liver. The liver releases the bilirubin in a fluid called bile. If the liver is not functioning correctly, the bilirubin will not be properly released. Therefore, if the bilirubin level is higher than expected, it may mean the liver is not functioning correctly.

(B) The liver is inflamed and diseased. Dysfunction in processing bilirubin by a diseased liver leads to increased loss in the urine. Increases in AST and GGT, liver-associated enzymes, suggest an infection or that some abnormal liver process is occurring.

(C) Unsterile tattoo needles and reused tattoo ink have likely led to a viral infection, probably hepatitis $\mathrm{C}$ (the timeframe favors hepatitis C (HCV) over hepatitis B; however, either answer would be correct here).

(D) After exposure to $\mathrm{HCV}$, which likely was from the unsterile needle and reused tattoo ink, it takes $\sim 8-11$ weeks for an HCV antibody test to be positive. After exposure, the anti-HCV blood test becomes positive in most people by 6 months after exposure.

\subsection{Clinical Science Cases}

Clinical science cases are a feature of the class that has remained very popular with the students. Combining basic biological principles with some clinical significance gives the students a genuine appreciation for how science is intertwined with medicine. Thus, while reminding them that their instructor is a scientist, not a physician, we forge ahead with clinical science cases each year.

Here are examples of two clinical science cases involving white blood cells in response to an infection (bacterial and viral, respectively). In this second unit of the class, we have migrated from red blood cells to white blood cells. The students have had lectures on Acute Inflammation and Granulocytes (primarily neutrophils), Complement, Chronic Inflammation and Mononuclear Leukocytes (monocytes, macrophages, and lymphocytes), Lymphocytes (B- and T-cells), and Innate and Adaptive Immunity. The students should now be ready to spend time working together on these clinical cases regarding white blood cells.

\section{Active Learning Clinical Science Cases on White Blood Cells}

Case 1. A 25-year-old female has a painful, inflamed, swollen hand. A cat bit her about $8 \mathrm{~h}$ ago. You were able to culture small Gram-negative rods in the exudate from the 
lesion. (1) What type of organism is this from the cat (do an online search)? (2) Why is the lesion inflamed, swollen and red? (3) What inflammatory cell would be found in the lesion? (4) What should be done in terms of treatment and therapy?

Answers to Case 1:

(1) Pasteurella multocida is a common small Gram-negative bacterium present in the normal oral and respiratory tracts of cats, which could be transmitted from a bite.

(2) This is acute inflammation, with all of the cardinal signs of inflammation from Celsus revealed. The lesion is likely inflamed, swollen, and red, as the process of fighting the invading bacteria is initiated, where fluid and white blood cells accumulate at the sight of the injury. This would include the recruitment of white blood cells, especially neutrophils, and activation of a complement to promote further migration of cells and generate mediators of inflammation.

(3) Neutrophils would likely be found in the lesion, in response to the presence of bacteria.

(4) The treatment would likely need to be wound-cleaning and broad-spectrum antibacterial ointment. Perhaps the patient may need some sort of antibiotic, then the physician would consider penicillin-related compounds as a first-line defense, and in the case of penicillin-resistant strands, cephalosporins, fluoroquinolones, and tetracyclines would be recommended.

Case 2. A 65-year-old male complains of a painful eruption of a rash on his left shoulder, which has progressed for $\sim 24 \mathrm{~h}$. The rash is vesicular and appears only on that side of the body. The rash consists of blisters that have scabbed over, and the pain is described as an intense burning sensation. He is currently being treated with cytotoxic chemotherapy for leukemia. The histological viewing of tissue from the base of the vesicle reveals multinucleated giant cells (a type of mononuclear leukocytes, i.e., macrophages) and lymphocytes. He reports having had chickenpox as a child. (1) What is the suspected diagnosis? (2) Is this an acute or chronic inflammatory cell response? (3) How would you distinguish the varicella-zoster virus from the herpes simplex type 1 virus? (4) What impact does the chemotherapy have on his immune system? (5) Are there any anti-viral drugs for treating the rash, especially for reducing the pain? (6) The patient wants to know if his 64-year-old spouse should get the shingles herpes zoster vaccine?

Answers to Case 2:

(1) Herpes zoster (shingles) is caused by the varicella-zoster virus. The rash of zoster follows the dermatome of the neuron that was latently infected. The picture (not shown here) reveals the prototypical appearance of the rash, accompanied by shingles.

(2) This is a chronic inflammatory process, with mononuclear cells responding to the viral infection.

(3) Herpes simplex type 1 virus can cause a similar rash. One can distinguish these viruses using a test with a fluorescently labeled antibody specific for each virus.

(4) After acute infection by the varicella-zoster virus, usually seen in childhood as chickenpox, the virus remains dormant in the dorsal nerve root ganglia until some change in the immune system. Chemotherapy made him more susceptible to viral outgrowth by the suppression of bone marrow and mononuclear leukocytes (lymphocytes and monocytes).

(5) There is some uncertainty regarding the impact of antiviral therapy on pain outcomes in patients with herpes zoster. When prescribing antiviral therapy, valacyclovir and famciclovir may be superior to acyclovir in achieving cessation of pain.

(6) Clinical trials have shown that anyone over the age of 60 should strongly consider getting the shingles herpes zoster vaccine; however, those with immunodeficiency should not be given this vaccine (a series of shots).

\subsection{Medical Role-Playing}

Role-playing is essentially acting or assuming a role during a reenactment. One has no way of understanding how or why it works, until one walks around the classroom and 
listens to the conversations going on within each group in class. Although there is adlibbing, it is still carefully orchestrated because each team member has a specific role, they are given specific questions to ask, and they each have test results to share with their team. We do medical role-playing twice during the semester; first, during the active learning session for "Introduction to Cancer," and second, during the active learning session for "Platelet Disorders".

\subsubsection{Description of Medical Role-Playing}

Ground Rules to Prepare for the Patient Interview. (a) Assign roles for each group member. Everyone has time to read over their specific material (2-3 min). (b) Begin interviewing patient/parent/spouse (partner) in this order: nurse (2-3 min), medical student (2-3 min), physician (2-3 min), and consult with specialists (pathologist/radiologist) (2-3 min). Interviews are conducted 1:1 in the presence of the entire group, who are listening/participating, but with each student's "character" leading the questioning and then providing the results. Yes, it is somewhat contrived. (c) The entire group meets to discuss the diagnosis, prognosis, and strategy for treatment, and fill out the H\&P as described in the "Methods" section (12-15 min). (d) The presentation to explain their findings means that one group presents their patient and case, with the other two groups contributing any additional information. This is performed for all three patients/cases by the nine groups (8-12 min).

Patient Interview and Medical Team Tips. Each member of the medical team has a vital and supportive role. The team gathers facts/information about their patient and their respective medical conditions/family/environment. Therefore, they try to ask meaningful questions. The team is trying to solve a mystery-what is wrong with your patient? What tests should be ordered? The patient does not walk in with a "label" on their forehead that says, "I have !" The team must be kind, thoughtful, and show empathy with the patient and their family, not sympathy. Finally, the team must respect and value their entire medical team, because they each serve an important role.

\subsubsection{Active Learning Medical Role-Playing during "Introduction to Cancer"}

The timing of medical role-playing is during the initial presentation of cancer in general, and specifically, hematological malignancies. Thus, cell phones/tablets/laptop computers and access to perform internet searches are essential components to each student during medical role-playing. Presented here are two of the six medical role-playing scenarios created for the class.

Patient 1: Diagnosis, Prognosis and Treatment-Findings from the Hematopathology lab are presented to the physician with a diagnosis of acute lymphoblastic leukemia (ALL), with an overall "good-to-excellent" prognosis in Table 4. Based on the bone marrow findings, this is classified as common precursor B-cell ALL. Strategy for treatment for ALL typically consists of remission induction, consolidation (or intensification) and maintenance (or continuation) therapies, and CNS prophylaxis, as well as the management of relapse.

Patient 2 Diagnosis, Prognosis and Treatment-Findings from the hematopathology lab are presented to the physician with a diagnosis of chronic myelocytic leukemia (CML) with an overall "excellent" prognosis in Table 5. Based on CBC and bone marrow findings, this is diagnosed as chronic-phase CML. The strategy for the treatment for CML includes a first-generation BCR-ABL kinase inhibitor, Imatinib (Gleevec), and it is taken orally daily. The only side effects include swelling or puffiness of the skin, nausea, muscle cramps, rash, fatigue, diarrhea, and skin rashes. Regular BCR-Abl screening by rt-PCR will monitor therapy and health. The physician will also present an option for a BM transplant, with issues of morbidity/mortality. Patient and spouse choose Gleevec. 
Table 4. Patient 1 Medical Role-Playing.

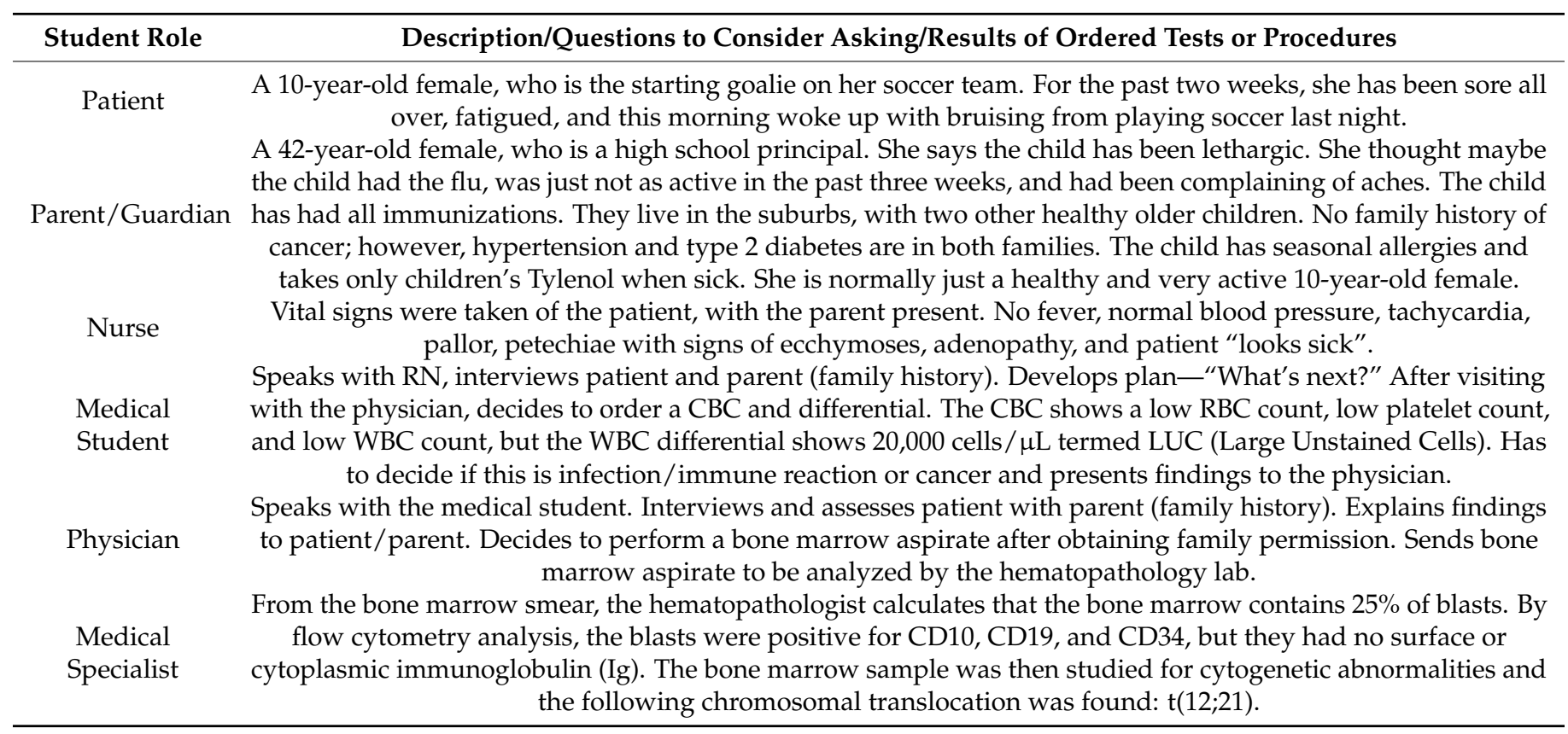

Table 5. Patient 2 Medical Role-Playing.

\section{Student Role}

Patient

Spouse/Partner

Nurse

Medical Student

Physician

Medical Specialist(Hematopathologist)

\section{Description/Questions to Consider Asking/Results of Ordered Tests or Procedures}

A 49-year-old male, who is a think-tank political analyst, once divorced, re-married, and with 2 children and 3 step-children. He is $5^{\prime} 9^{\prime \prime}$, and is overweight but not obese. He eats 3 packs of cheese crackers (nabs) and 1 Moon Pie every day, along with 6 Coke Zeroes. He walks the family dog at night, but he cannot miss the nightly Fox News report. He smokes about 5-10 cigarettes per day, and socially drinks alcohol (he prefers rum and Coke Zero). He played high school baseball but has not exercised regularly since graduating from law school. He has a significant family history of cardiovascular disease (CVD), his father died of a heart attack at 48 y.o.; his uncle has had 3 heart attacks in his 50s, and his mother (65 y.o.) has both hypertension and atherosclerosis. For the past decade, his wife has been asking him to get a physical and change his lifestyle. Thus, he presents for his first physical exam since college. He takes a multiple vitamin supplement daily, when he remembers, had the flu last year,

has a hacking cough from smoking, and has tried Nicorette gum to stop smoking. A 48-year-old female, who is the anchor at the local community news TV station. In her spare time, she is an award-winning children's book author, and participates in 2-3 marathons/year. She is a vegetarian and neither smokes nor drinks. She is very concerned about her husband's family history, current lifestyle, diet, lack of exercise, and potential risk of CVD.

Vital signs of the patient were taken with the spouse present. Height 68 inches, $190 \mathrm{lbs}(\mathrm{BMI}=29$, overweight). No fever, normal blood pressure, no heart murmur, patient "looks prosperous", with chubby cheeks. The patient has no aches/pains, he feels healthy.

Speaks with RN, interviews the patient and spouse (gets family history). Develops plan-“'What's next?" After consulting with the physician, decides to order $\mathrm{CBC}$ with differential and full blood panel for CVD (cholesterol, lipids, HDL, LDL, liver and kidney function, electrolytes, uric acid, etc.). CBC shows normal RBC count, normal platelet count, a high WBC count of 30,000 (nl 4000-10,800), and, from the WBC differential, shows a "left shift" with the presence of band neutrophils, metamyelocytes, myelocytes, and promyelocytes. Has to decide if this is benign infection/immune reaction (leukemoid reaction) or cancer? Presents findings to the physician.

Speaks with the medical student. Interviews and assesses patient, with spouse (family history). Explain findings to the patient/spouse. The physician gets consent for a bone marrow aspirate. Decides to send the blood and aspirate to be further analyzed by the hematopathology lab.

From the blood smear, the hematopathologist verifies the WBC differential (band neutrophils, metamyelocytes, myelocytes, and promyelocytes). Based on the substantial left shift (the sheer number of these cells present), they decide that this is not a benign infectious event. Furth proof was obtained from the FISH (fluorescent in situ hybridization) and rt-PCR studies on the leukocytes from the bone marrow aspirate. The results reveal the same thing; the $B C R-A b l$ oncogene, more specifically, $\mathrm{t}(9 ; 22)$. 


\section{Discussion}

"I never teach my pupils, I only attempt to provide the conditions in which they can learn." Albert Einstein

Active learning teaching methods can be time-consuming in terms of both instructor preparation and class integration, and our previous results suggested that subtype analysis can help instructors prioritize the integrated techniques [20]. Our previous results also showed that the active learning methods incorporated into the classroom environment positively affected student comprehension [20]. The current paper gives actual examples of the material taught to the students during active learning periods, from the undergraduate biology course entitled "Biology of Blood Diseases."

Analytical engagement was the most complex aspect of active learning attempted in the course. These learning exercises challenged the students and emphasized the teambased skills aspect of active learning (Figure 3). All three of the active learning exercise types required that the students collaborate with their groups. It was also necessary that they had conversations about the material, to understand the key points better. Furthermore, they had to coordinate their actions to formulate the most appropriate responses. Finally, they had forms and answers to compile as a group, on which their grades depended during the semester. Thus, these examples of analytical engagement nicely highlighted what could be termed the four " $\mathrm{C}$ 's" of team-based skills in active learning (Figure 3).

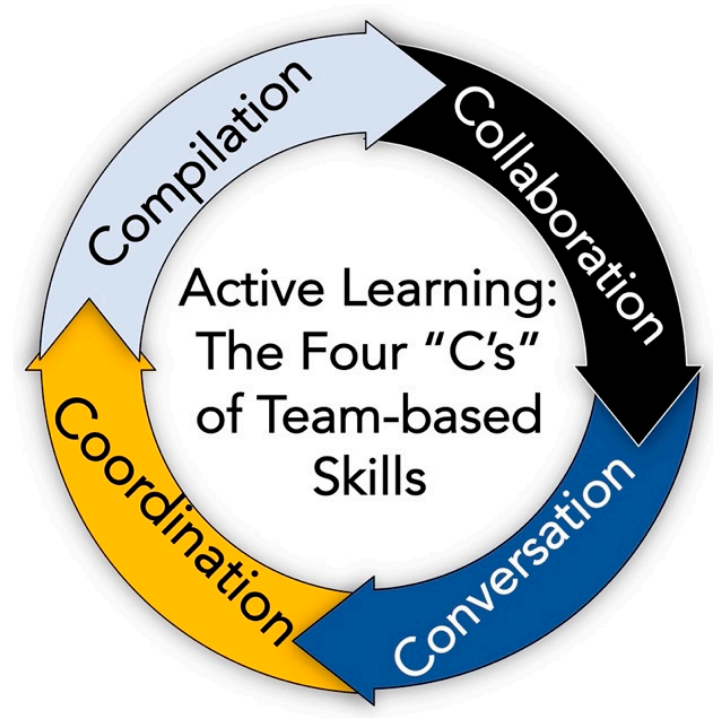

Figure 3. Developing and implementing these analytical engagement exercises enables the students to practice and improve their team-based skills of collaboration, conversation, coordination, and compilation.

The role-playing of medical problems is based on the notion that play-acting can impart feelings regarding the patient scenario and provide a setting that offers a real-world medical situation and a well-rounded, empathetic team. There is much use for role-playing in medical and other professional schools. For example, Chan [48] used role play in a problem-based learning situation. Developing empathy was a goal of this medical school's attempt to utilize medical role-playing [49]. In addition, medical role-playing was used to study the development of critical thinking in nursing students [50].

Although the cases used here were much simplified, the knowledge taught, and the lessons learned and remembered were similar to those of medical students. Medical students most appreciate the effectiveness of clinical case-based learning in medical school, and they feel it enhances their learning process [51,52]. Likewise, case method teaching was a practical approach to combining basic and clinical sciences into the classroom phase of medical school [52]. Again, the cases used here were much less detailed than those 
found in medical school, but merging basic and clinical science principles were the key goals of using medical cases.

The basic science workshops used here were focused on applying the foundational knowledge of science into an application of biology and medicine. Similarly, the principle of anatomy used in clinical applications suggests that understanding the clinical problem was linked to exploring and knowing basic science concepts [53]. In another study, using self-directed basic science modules enhanced the clinical aspects of medical school education [51]. Finally, integrating basic science and clinical science cases improved the student learning environment [52].

The goal was to describe the material offered to the class in the area termed analytical engagement. It is also the most challenging and most time-consuming aspect to preparing for teaching from the faculty perspective, and from learning from the student's viewpoint. The active learning survey given to the class (2012-present) was optional, and the final open-ended question has generated $\sim 100$ responses regarding active learning. Several comments compiled from the class surveys regarding student opinion about active learning in general, group settings, and clinical exercises include:

"Answering questions and engaging with problems makes it much easier for me to recognize what I do not understand and what I need to review more. Plus, I feel like I am able to learn a lot from my peers because we all have different elements of the material that we understand and can help explain to one another."

"I loved the pace of the class with active learning weekly intertwining with the classic lecture-style learning. Thank you for that."

"Working together for the clinical sessions for the Active Learning was very helpful because we were able to work together to figure out the important information and synthesize it to come up with the right diagnosis."

"I loved active learning days. They really helped me understand what I was learning but also apply them to real-world scenarios. Doing the clinical exercise at the end really helped me put together my knowledge and made it much easier for me to learn the information and study it for exams. A lot of the information I learned from active learning I still remember and know better than some of the lecture material because being able to apply what we learn in the lectures stuck better in my mind and prepared me more for what I want to do in the future."

\section{Conclusions}

Giving a lecture is somewhat like performing a solo concert on stage, which means the audience is listening, and only rarely do they interrupt while one is playing (lecturing). By contrast, when conducting the orchestra (class) during an active learning session, the students perform and make music while the conductor coordinates/facilitates their performance. Ultimately, the type of music played (method of learning) is chosen by the instructor. Thus, while producing different music rather than a solo concert, following an active learning teaching plan potentially offers a win-win scenario for both the conductor (teacher) and the orchestra (student learners).

The traditional lecture remains popular for teaching science at the university level [54]. However, we now know that learning is complex [1-19], and that students learn (e.g., store and recall information, remember, and process material) differently and individually $[18,19]$. Furthermore, our previous study found that active learning subtypes improved comprehension in a science course [20]. Hopefully, the depiction of analytical engagement here has provided ample examples for others to consider adapting their courses from a traditional lecture-only format to including elements of active learning subtypes.

Funding: This research received no external funding.

Institutional Review Board Statement: This project was conducted under the guidelines of UNC IRB 19-02137. Consent was given to examine student data; thus, no human subjects were involved in the study. 
Informed Consent Statement: Not applicable.

Data Availability Statement: Not applicable.

Acknowledgments: F.C.C. is most grateful to all of the students of "Biology of Blood Diseases"; it has been an honor and privilege teaching you and for allowing me the opportunity to develop, implement, and test the active learning methods described here. F.C.C. thanks Casey A. Hribar for useful suggestions in critiquing the manuscript. F.C.C. thanks Raj Kasthuri for advice in medical role-playing. F.C.C. gratefully acknowledges Russell R. Broaddus, the Joe W. and Evelyn M. Grisham Distinguished Professor and Department Chair in the Department of Pathology and Laboratory Medicine at UNC School of Medicine, for his continued support of my education research/scholarship.

Conflicts of Interest: The author declares no conflict of interest.

\section{References}

1. Bonwell, C.C.; Eison, J.A. Active Learning: Creating Excitement in the Classroom. 1991 ASHE-ERIC Higher Education Reports; ERIC: Washington, DC, USA, 1991.

2. Grabinger, R.S.; Dunlap, J.C. Rich environments for active learning: A definition. ALT-J 1995, 3, 5-34. [CrossRef]

3. Cohn, D.; Atlas, L.; Ladner, R. Improving generalization with active learning. Mach. Learn. 1994, 15, 201-221. [CrossRef]

4. Phillips, J.M. Strategies for active learning in online continuing education. J. Contin. Educ. Nurs. 2005, 36, 77-83. [CrossRef] [PubMed]

5. Schon, D.A. Educating the reflective practitioner: Toward a new design for teaching and learning in the professions. Aust. J. Adult Learn. 2010, 50, 448-451.

6. Walker, S.E. Active learning strategies to promote critical thinking. J. Athl. Train. 2003, 38, 263.

7. Felder, R.M.; Brent, R. Active learning: An introduction. ASQ High. Educ. Brief 2009, 2, 1-5.

8. Hyun, J.; Ediger, R.; Lee, D. Students' Satisfaction on Their Learning Process in Active Learning and Traditional Classrooms. Int. J. Teach. Learn. High. Educ. 2017, 29, 108-118.

9. Millis, B.J.; Cottell, P.G., Jr. Cooperative Learning for Higher Education Faculty. Series on Higher Education; ERIC: Washington, DC, USA, 1997.

10. Brown, G.A.; Bull, J.; Pendlebury, M. Assessing Student Learning in Higher Education; Routledge: Oxfordshire, UK, 2013.

11. Auerbach, A.; Higgins, M.; Brickman, P.; Andrews, T. Teacher knowledge for active-learning instruction: Expert-novice comparison reveals differences. CBE Life Sci. Educ. 2018, 17, ar12. [CrossRef]

12. Johnson, R.T.; Johnson, D.W. Active learning: Cooperation in the classroom. Annu. Rep. Educ. Psychol. Jpn. 2008, 47, 29-30. [CrossRef]

13. Roehl, A.; Reddy, S.L.; Shannon, G.J. The flipped classroom: An opportunity to engage millennial students through active learning strategies. J. Fam. Consum. Sci. 2013, 105, 44-49. [CrossRef]

14. Freeman, S.; Eddy, S.L.; McDonough, M.; Smith, M.K.; Okoroafor, N.; Jordt, H.; Wenderoth, M.P. Active learning increases student performance in science, engineering, and mathematics. Proc. Natl. Acad. Sci. USA 2014, 111, 8410-8415. [CrossRef] [PubMed]

15. Eddy, S.L.; Hogan, K.A. Getting under the hood: How and for whom does increasing course structure work? CBE Life Sci. Educ. 2014, 13, 453-468. [CrossRef]

16. Haak, D.C.; HilleRisLambers, J.; Pitre, E.; Freeman, S. Increased structure and active learning reduce the achievement gap in introductory biology. Science 2011, 332, 1213-1216. [CrossRef]

17. Sathy, V.; Hogan, K.A. Want to Reach All of Your Students? Here's How to Make Your Teaching More Inclusive. Available online: https: / / ctle.test.utah.edu/inclusiveteaching/resources/landing_links/How\%20to\%20Make\%20Your\%20Teaching\%20 More $\% 20$ Inclusive $\% 20-\% 20$ The $\% 20$ Chronicle $\% 20$ of $\% 20 H i g h e r \% 20$ Education.pdf (accessed on 1 June 2021).

18. Allen, D.; Tanner, K. Rubrics: Tools for making learning goals and evaluation criteria explicit for both teachers and learners. $C B E$ Life Sci. Educ. 2006, 5, 197-203. [CrossRef] [PubMed]

19. Tanner, K.; Allen, D. Approaches to biology teaching and learning: Learning styles and the problem of instructional selectionengaging all students in science courses. Cell Biol. Educ. 2004, 3, 197-201. [CrossRef] [PubMed]

20. McGreevy, K.M.; Church, F.C. Active Learning: Subtypes, Intra-Exam Comparison, and Student Survey in an Undergraduate Biology Course. Educ. Sci. 2020, 10, 185. [CrossRef]

21. Krathwohl, D.R. A revision of Bloom's taxonomy: An overview. Theory Pract. 2002, 41, 212-218. [CrossRef]

22. Forehand, M. Bloom's taxonomy. In Emerging Perspectives on Learning, Teaching, and Technology; Available online: https://www.d4 1.org/cms/lib/IL01904672/Centricity/Domain/422/BloomsTaxonomy.pdf (accessed on 1 June 2021).

23. Anderson, L.W.; Sosniak, L.A. Bloom's Taxonomy; Univ. Chicago Press: Chicago, IL, USA, 1994.

24. Fink, L.D. Creating Significant Learning Experiences: An Integrated Approach to Designing College Courses; John Wiley \& Sons: Hoboken, NJ, USA, 2013.

25. Anderson, L.W.; Bloom, B.S. A Taxonomy for Learning, Teaching, and Assessing: A Revision of Bloom's Taxonomy of Educational Objectives. Longman. Available online: https:/ / eduq.info/xmlui/handle/11515/18345 (accessed on 1 June 2021). 
26. Conklin, J. A Taxonomy for Learning, Teaching, and Assessing: A Revision of Bloom's Taxonomy of Educational Objectives. Available online: https:/ / www.jstor.org/stable/42926529 (accessed on 1 June 2021).

27. $\mathrm{Ng}, \mathrm{M} . ;$ Newpher, T.M. Comparing active learning to team-based learning in undergraduate neuroscience. J. Undergrad. Neurosci. Educ. 2020, 18, A102. [PubMed]

28. Penner, M.R.; Sathy, V.; Hogan, K.A. Inclusion in neuroscience through high impact courses. Neurosci. Lett. 2021, 750, 135740. [CrossRef]

29. Evans, L.; Bosch, M.L.V.; Harrington, S.; Schoofs, N.; Coviak, C. Flipping the classroom in health care higher education: A systematic review. Nurse Educ. 2019, 44, 74-78. [CrossRef]

30. Johnson, K.M. Implementing inclusive practices in an active learning STEM classroom. Adv. Physiol. Educ. 2019, 43, 207-210. [CrossRef] [PubMed]

31. Santos, J.; Figueiredo, A.S.; Vieira, M. Innovative pedagogical practices in higher education: An integrative literature review. Nurse Educ. Today 2019, 72, 12-17. [CrossRef] [PubMed]

32. Knudson, D. Active learning and student beliefs about learning. ISBS Proc. Arch. 2019, 37, 328.

33. Deslauriers, L.; McCarty, L.S.; Miller, K.; Callaghan, K.; Kestin, G. Measuring actual learning versus feeling of learning in response to being actively engaged in the classroom. Proc. Natl. Acad. Sci. USA 2019, 116, 19251-19257. [CrossRef]

34. Vasan, N.S.; DeFouw, D.O.; Compton, S. A survey of student perceptions of team-Based learning in anatomy curriculum: Favorable views unrelated to grades. Anat. Sci. Educ. 2009, 2, 150-155. [CrossRef]

35. Keohane, E.M.; Otto, C.N.; Walenga, J.M. Rodak's Hematology-E-Book: Clinical Principles and Applications; Elsevier Health Sciences: Philadelphia, PA, USA, 2019.

36. Kottke-Marchant, K.; Davis, B. Laboratory Hematology Practice; Wiley Online Library: Hoboken, NJ, USA, 2012.

37. Mehta, A.B.; Hoffbrand, A.V. Haematology at A Glance; John Wiley \& Sons: Hoboken, NJ, USA, 2009; Volume 5.

38. Hoffbrand, A.; Peltit, J.; Moss, P. Essential Hematology. Available online: https://www.academia.edu/41414771/Essential_ Haematology_Hoffbrand_Victor_Moss_Paul (accessed on 1 June 2021).

39. Hatton, C.S.; Hay, D.; Keeling, D.M. Haematology; John Wiley \& Sons: Hoboken, NJ, USA, 2017.

40. Goljan, E.F. Rapid Review Pathology: With Student Consult Online Access. Available online: https://books.google.com.hk/books?

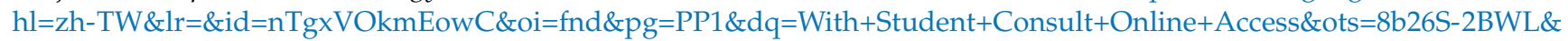
sig=03xf4p1liIag1tyPO35dSY_pPec\&redir_esc=y\#v=onepage\&q=With\%20Student $\% 20$ Consult $\% 200$ nline $\% 20$ Access\&f=false (accessed on 1 June 2021).

41. Rubin, E.; Reisner, H.M. Essentials of Rubin's Pathology; Lippincott Williams \& Wilkins: Philadelphia, PA, USA, 2009.

42. Rubin, R.; Strayer, D.S.; Rubin, E. Rubin's Pathology: Clinicopathologic Foundations of Medicine; Lippincott Williams \& Wilkins: Philadelphia, PA, USA, 2008.

43. Kumar, V.; Abbas, A.K.; Fausto, N.; Aster, J.C. Robbins and Cotran Pathologic Basis of Disease, Professional Edition E-Book; Elsevier Health Sciences: Philadelphia, PA, USA, 2014.

44. Abrahamian, F.M.; Goldstein, E.J. Microbiology of animal bite wound infections. Clin. Microbiol. Rev. 2011, 24, 231-246. [CrossRef]

45. Davis, A.P.; Marra, C.M.; Khot, S.P. Diagnostic dilemma of a young man with Fever and headaches. Neurohospitalist 2012, 2, 156-162. [CrossRef]

46. Sattar, A.H. Fundamentals of Pathology: Medical Course and Step 1 Review. Available online: http://125.212.201.8:6008/handle/ DHKTYTHD_123/7611 (accessed on 1 June 2021).

47. Poynard, T.; Yuen, M.-F.; Ratzin, V.; Lai, C.L. Viral hepatitis C. Lancet 2003, 362, 2095-2100. [CrossRef]

48. Chan, Z.C. Role-playing in the problem-based learning class. Nurse Educ. Pract. 2012, 12, 21-27. [CrossRef]

49. Newton, B.W.; Savidge, M.A.; Barber, L.; Cleveland, E.; Clardy, J.; Beeman, G.; Hart, T. Differences in Medical Students' Empathy. Available online: https:/ / psycnet.apa.org/record/2000-14369-001. (accessed on 1 June 2021).

50. Ertmer, P.A.; Strobel, J.; Cheng, X.; Chen, X.; Kim, H.; Olesova, L.; Sadaf, A.; Tomory, A. Expressions of critical thinking in role-playing simulations: Comparisons across roles. J. Comput. High. Educ. 2010, 22, 73-94. [CrossRef]

51. Khalil, M.K.; Nelson, L.D.; Kibble, J.D. The use of self-learning modules to facilitate learning of basic science concepts in an integrated medical curriculum. Anat. Sci. Educ. 2010, 3, 219-226. [CrossRef]

52. Bick, R.J.; Oakes, J.L.; Actor, J.K.; Cleary, L.J.; Felleman, D.J.; Ownby, A.R.; Weisbrodt, N.W.; Seifert, W. Interactive teaching: Problem solving and integration of basic science concepts into clinical scenarios using team-based learning. J. Int. Assoc. Med. Sci. Educ. 2009, 19, 26-34.

53. Balla, J.I.; Biggs, J.; Gibson, M.; Chang, A.M. The application of basic science concepts to clinical problem-Solving. Med Educ. 1990, 24, 137-147. [CrossRef] [PubMed]

54. Stains, M.; Harshman, J.; Barker, M.K.; Chasteen, S.V.; Cole, R.; DeChenne-Peters, S.E.; Eagan, M.; Esson, J.M.; Knight, J.K.; Laski, F.A. Anatomy of STEM teaching in North American universities. Science 2018, 359, 1468-1470. [CrossRef] 